\title{
6-(4-Aminophenyl)-4,5-dihydro-3(2H)-pyridazinone - An important chemical moiety for development of cardioactive agents: A review
}

\author{
Mohd Imran* and Abida \\ Department of Pharmaceutical Chemistry, Faculty of Pharmacy, Northern Border University, Rafha 91911, PO Box 840, \\ Kingdom of Saudi Arabia \\ *For correspondence: Email: imran_inderlok@yahoo.co.in; Tel: +966535129629 \\ Received: 4 July 2015 \\ Revised accepted: 16 April 2016

\begin{abstract}
6-(4-Aminophenyl)-4,5-dihydro-3(2H)-pyridazinone moiety is a vital structural part of many cardio-active pyridazinone derivatives which are either in clinical use or have been tested in clinical trials. These include imazodan, Cl-930, pimobendan, indolidan, levosimendan, SK\&F-93741, Y-590, meribendan, NSP-804, NSP-805, bemoradan, senazodan, amipizone, prinoxodan, SKF 95654, siguazodan and KF 15232. This article briefly reviews relevant literature on various reports on the synthesis and use of this moiety for development of cardio-active agents.
\end{abstract}

Keywords: 6-(4-Aminophenyl)-4,5-dihydro-3(2H)-pyridazinone, Cardio-active agents, Imazodan, Pimobendan, Indolidan, Levosimendan

\begin{abstract}
Tropical Journal of Pharmaceutical Research is indexed by Science Citation Index (SciSearch), Scopus, International Pharmaceutical Abstract, Chemical Abstracts, Embase, Index Copernicus, EBSCO, African Index Medicus, JournalSeek, Journal Citation Reports/Science Edition, Directory of Open Access Journals (DOAJ), African Journal Online, Bioline International, Open-J-Gate and Pharmacy Abstracts
\end{abstract}

\section{INTRODUCTION}

Cardiovascular disease is a major public health problem worldwide, even in the United States of America, and it accounts for approximately $30 \%$ of all deaths [1]. Cardiovascular disease has also been considered to be the major cause of death in the Kingdom of Saudi Arabia [2]. Due to increasing prevalence of cardiovascular disease in children, researchers have recommended the establishment of well-equipped hospitals to for the care of children with cardiovascular disease in developing countries as well as in Kingdom of Saudi Arabia [3]. Studies have also revealed that there is a need for more research in the field of cardiovascular disease in developing countries because of the likelihood of prevalence of cardiovascular disease in all age groups in these countries $[4,5]$.
There are many cardio-active derivatives of 6-(4aminophenyl)-4,5-dihydro-3(2H)-pyridazinone containing 6-(4-aminophenyl)-4,5-dihydro-3(2H)pyridazinone moiety (1) as their vital structural component. These derivatives are either in clinical use or have been tested in clinical trials. They include imazodan [6,7]; Cl-930 [7,8]; pimobendan [7,9]; indolidan [7,10]; levosimendan $[7,11] ; \quad S K \& F-93741 \quad[7,12] ; \quad Y-590 \quad[7,13] ;$ meribendan [14]; NSP-804 [15]; NSP-805 [15]; bemoradan [16,17]; senazodan [18]; amipizone [7,17]; prinoxodan [19]; SKF 95654 [20]; siguazodan [21] and KF 15232 [21].

Some reviews on pyridazinone derivatives have been published [22-25]. However, these reviews are directed towards the general chemistry and general biological activities of diverse pyridazine 
derivatives. None of these articles focused on the use of any specific chemical moiety for the development of cardio-active agents.

The current review gives an insight on the potential of 6-(4-aminophenyl)-4,5-dihydro-3(2H)pyridazinone moiety for the development of cardio-active agents, and briefly discusses relevant literature related to the synthesis and use of this chemical for the preparation of cardioactive agents. Accordingly, literature references wherein 6-(4-aminophenyl)-4,5-dihydro-3(2H)pyridazinone moiety was not synthesized and/or not used for the preparation of cardio-active agents were excluded.<smiles>Nc1ccc(C2=NNC(=O)CC2)cc1</smiles>

1<smiles>O=C1CCC(c2ccc(-n3ccnc3)cc2)=NN1</smiles>

Imazodan<smiles>COc1ccc(-c2nc3cc(C4=NNC(=O)CC4C)ccc3[nH]2)cc1</smiles><smiles>CC1(C)C(=O)Nc2ccc(C3=NNC(=O)CC3)cc21</smiles><smiles>C[C@@H]1CC(=O)NN=C1c1ccc(NN=C(C#N)C#N)cc1</smiles><smiles>CC(=O)Nc1ccc(C2=NNC(=O)CC2C)cc1</smiles>

SK\&F-93741<smiles>CC1CC(=O)NN=C1c1ccc2c(c1)CCC(=O)N2C</smiles>

Y 590<smiles>CC1CC(=O)NN=C1c1ccc2[nH]c(-c3cc[nH]n3)nc2c1</smiles>

Meribendan<smiles>CC1=C(Nc2ccc(C3=NNC(=O)CC3)cc2)CCC1=O</smiles> 
<smiles>CC1=C(Nc2ccc(C3=NNC(=O)CC3C)cc2)CCC1=O</smiles><smiles>CC1CC(=O)NN=C1c1ccc2c(c1)OCC(=O)N2</smiles>

Bemoradan<smiles>O=C1CCC(c2ccc(Nc3ccncc3)cc2)=NN1</smiles><smiles>CN1Cc2cc(C3=NNC(=O)CC3)ccc2NC1=O</smiles><smiles>CC(Cl)C(=O)Nc1ccc(C2=NNC(=O)CC2C)cc1</smiles>

Amipizone<smiles>CNC(=Nc1ccc(C2=NNC(=O)CC2C)cc1)NC#N</smiles>

Siguazodan<smiles>C[C@H]1CC(=O)NN=C1c1ccc(-n2ccc(=O)cc2)cc1</smiles>

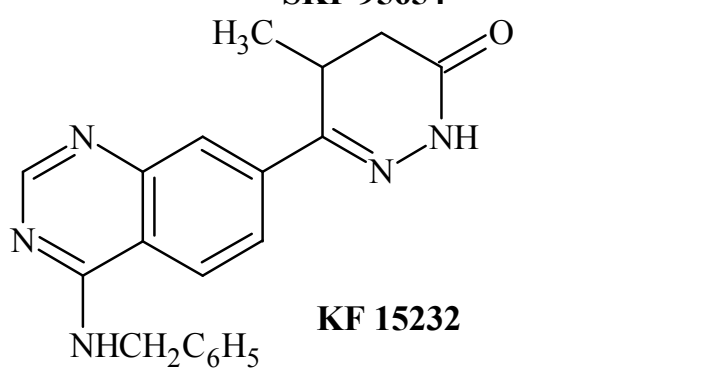

Figure 1: Some pyridazinone derivatives

\section{6-(4-AMINOPHENYL)-4,5-DIHYDRO-3(2H)- PYRIDAZINONE DERIVATIVES AS CARDIOACTIVE AGENTS}

6-(4-Aminophenyl)-4,5-dihydro-3(2H)pyridazinone (1) was first reported in 1967 by Gerhard and August [26]. Gerhard and August also reported that this compound is associated with anti-inflammatory and sustained blood pressure reducing activities [27].

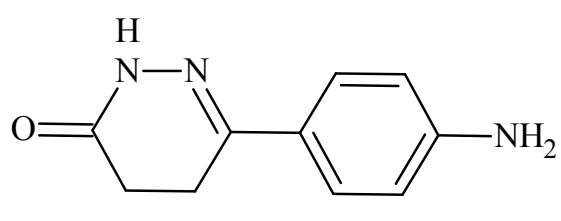

1

Curran and Ross [28] prepared and tested a series of 6-phenyl-4,5-dihydro-3(2H)pyridazinones. They concluded that the potent and most active hypotensive agents (2) in normotensive rats were derivatives with acetamido and cyano groups in the para or meta position of the benzene ring, combined with 5methyl substituent in the hetero ring.

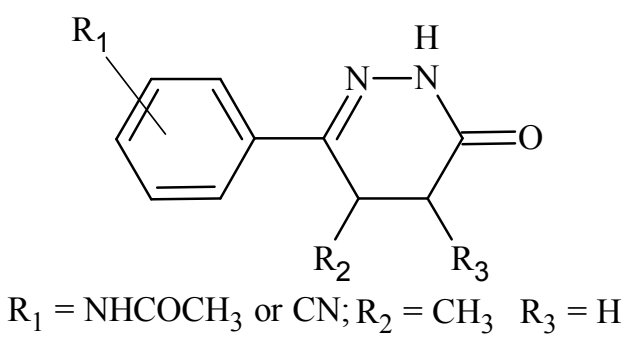

2

Thyes et al [29] prepared 6-Aryl-4,5-dihydro$3(2 \mathrm{H})$-pyridazinones which exhibited aggregation-inhibiting activity on human platelets in vitro and on rat platelets ex vivo, as well as a hypotensive action on rats. The strongest pharmacological effects were found with dihydropyridazinones that have $\mathrm{R}=$ chloroalkanoyl substituent, together with a methyl group in the 5-position (3). The hypotensive 
actions of these compounds were 40 times higher than that of dihydralazine.

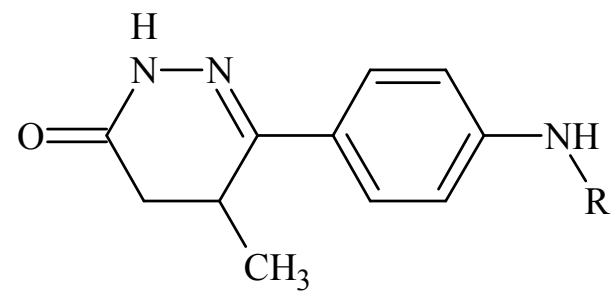

$$
\mathrm{R}=\text { chloroalkanoyl substituent }
$$

3

These authors further demonstrated that the para-substituted compounds had a strong inhibiting effect on collagen-induced and ADPinduced aggregation of human platelets. It is known that platelet aggregation plays an important role in the pathogenesis of cardiovascular disease [30].

The in vitro human platelet aggregation and the ex vivo rat platelet aggregation-inhibiting activities of 6-aryl-4,5-dihydropyridazinones (4) with $R_{1}=R_{2}=R_{4}=M e$ or $H$; and $R_{3}=$ amine containing, groups were correlated with the van der Waals volume (Vw) of $R_{3}$ by Gupta et al [31]. Their results suggested that the size of the substituent on the aryl group plays an important role in the inhibition of platelet aggregation in this series of compounds. Based on the correlating equations obtained, it was further suggested that the inhibition of platelet aggregation most likely involved hydrophobic interaction. A moderate correlation existed between the hypotensive activity of these drugs in rats and $\mathrm{Vw}$, indicating that hypotensive activity also was partly affected by the size of the substituent on the aryl group. Although it was assumed that hydrophobic interactions also played some role in the hypotensive action, it was argued, based on the results, that platelet aggregation inhibition and hypotensive activity involved two different receptor sites.

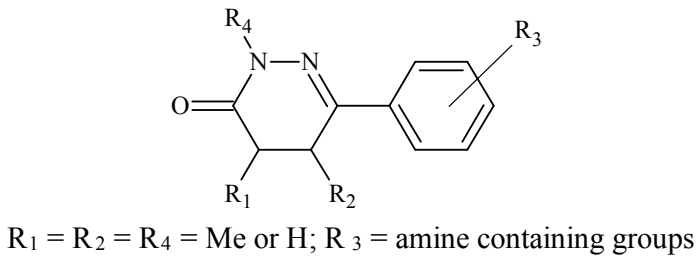

4

A series of 4,5-dihydro-6-[4-(1H-imidazol-1yl)phenyl]-3(2H)-pyridazinones and related compounds were synthesized and evaluated for positive inotropic activity by Sircar et al [32]. Most members of this series produced dose-related increases in myocardial contractility that were associated with relative minor increase in heart rate and decrease in systemic arterial blood pressure. Among the synthesized compounds (5), the one with $\mathrm{R}=\mathrm{H}(\mathrm{Cl}-914)$ and $\mathrm{R}=$ Methyl (Cl-930) were more potent than amrinone and milrinone, respectively. It was also postulated that the positive inotropic effect of these compounds was due to the inhibition of cardiac phosphodiesterase fraction III, rather than the stimulation of $\beta$-adrenergic receptors.
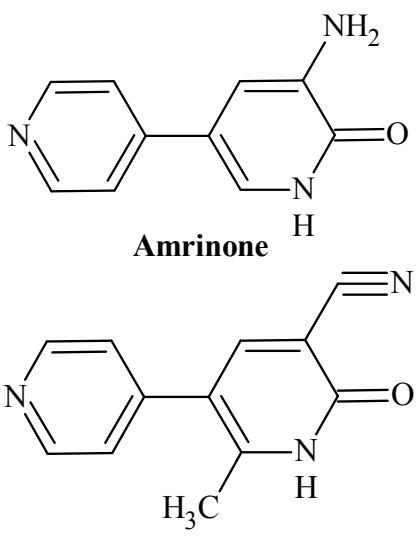

Milrinone

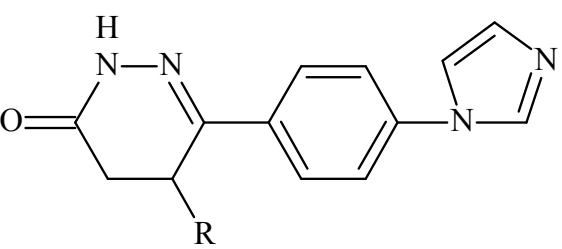

$\mathrm{R}=\mathrm{H}$ (CI-914); Methyl (CI-930)

5

Okushima et al [33] reported pyridazinone derivatives with cardiac activity. These pyridazinones, with $\mathrm{R}=\mathrm{H}$ and $\mathrm{Me} ; \mathrm{R}_{1}=4$-pyridyl, 2-pyridyl, 2-pyrimidyl and 4-quinolyl, were evaluated for inotropic activities in vitro and for cardio-hemodynamic effects in vivo. The hydrochloride salts of compound (6) with $\mathrm{R}=\mathrm{H}$ (MCl-154) or $\mathrm{Me}$ and $\mathrm{R}_{1}=4$-pyridyl showed extremely potent positive inotropic and vasodilating activities, and good $\mathrm{ED}_{50}$ relative to amrinone.

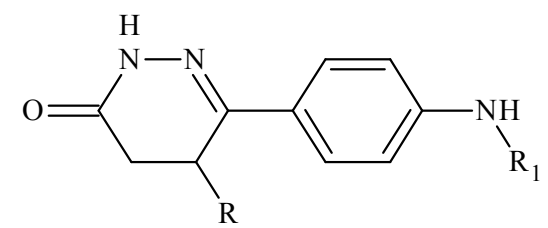

$\mathrm{R}=\mathrm{H}$ (MCI-154) or Me; $\mathrm{R} \quad{ }_{1}=4$-pyridyl

6

Sircar et al investigated the structure-activity relationships of a series of 4,5-dihydro-6-[4- $(1 \mathrm{H}-$ imidazol-1-yl)phenyl]-3-(2H)-pyridazinones with $\mathrm{R}=\mathrm{H}, \mathrm{Me}, \quad \mathrm{CH}_{2} \mathrm{Ph}, \quad \mathrm{CH}_{2} \mathrm{CH}_{2} \mathrm{OH}$, 
$\mathrm{CH}_{2} \mathrm{CH}_{2} \mathrm{OAc} ; \mathrm{R}_{1}=\mathrm{H}, \mathrm{Me}, \mathrm{NH}_{2}, \mathrm{CONH}_{2}$; and $\mathrm{R}_{2}=$ $\mathrm{H}$, Me, Et; $\mathrm{R}_{3}=\mathrm{H}, \mathrm{Me}, \mathrm{SH}$, SMe, SOMe, Et, for their in vivo inhibition of different forms of cyclic nucleotide phosphodiesterase (PDE) isolated from guinea pig ventricular muscle [34]. With few exceptions, these 4,5-dihydropyridazinones were potent inhibitors of cardiac type III phosphodiesterase. The most selective PDE III inhibitor was Cl-930 $\left(\mathrm{R}=\mathrm{R}_{1}=\mathrm{R}_{3}=\mathrm{H}, \mathrm{R}_{2}=\mathrm{Me}\right)$ with an $\mathrm{ED}_{50}$ of $0.6 \mu \mathrm{M}$.<smiles>[R]c1nccn1-c1ccc(C2=NN([R])C(=O)C([R])C2[R2])cc1</smiles>

Slater et al [35] reported the design and synthesis of a series of combined vasodilator- $\beta$ adrenoceptor antagonists based on 6arylpyridazinones, and evaluated them as vasodilator- $\beta$-adrenoceptor antagonists and potential antihypertensive agents. Many of the synthesized compounds showed high level of intrinsic sympathomimetic activities (ISA) and relatively short durations of action. Di-substitution in the 2,3-positions or in the 4-position of the aryloxy ring produced compounds with Iow ISA levels and, in some cases, improved duration of action. The 5-methylpyridazinone derivatives displayed more antihypertensive activity than their 5-H homologs. The compound, SK\&F 95018, was selected for further development.<smiles>NC(=O)CCNCC(O)COc1ccc(CCOCC2CC2)cc1</smiles>

SK\&F 95018

Benzodioxane pyridazinones (8) and benzodioxane dihydropyridazinone (9) have been reported as antihypertensive agents by Stefano et al [36]. Derivatives with $Z=1,4-d i-$ substituted piperazine showed good hypotensive activities, which were related to anti-adrenergic effects.<smiles>O=c1ccc([Z]CC2COc3ccccc3O2)n[nH]1</smiles><smiles>O=C1CCC(c2ccc(NCC3COc4ccccc4O3)cc2)=NN1</smiles>

Alfred et al [37] have reported 4,5-dihydro-6-(1Hindol-5-yl)-pyridazin-3(2H)-ones and related compounds with positive inotropic activities. Most of these compounds produced increases in myocardial contractility with little effects on heart rate and blood pressure. The cardiotonic effect of compound (10) was at least 2-fold higher than that of pimobendan following oral administration.
It has been suggested that, for optimal cardiotonic activity within this class of indole derivatives, a heterocyclic aromatic ring in position 2, a hydrogen or a Me group in position 3 and a dihydropyridazinone ring system in position 5 of the indole are necessary.<smiles>CC1CC(=O)NN=C1c1ccc2[nH]c(-c3ccncc3)cc2c1</smiles>

7-substituted-4,4a-dihydro-4a-methyl-5Hindeno[1,2-c]pyridazin-3[2H]-ones and 8Qubstituted-4a-methylbenzo[h]cinnolin-3[2H]-

ones have been synthesized and their PDE III inhibitory, inotropic and vasodilator potencies compared with those of their normethyl and their bicyclic 4,5-dihydro-6-phenylpyridazinone analogues by Bakewell et al [38]. The study revealed that the structure-activity relationships of the tricyclic pyridazinones differ from those of bicyclic pyridazinones mainly in respect of the effect produced by introducing a methyl group in the pyridazinone ring. Introduction of a 5-methyl group has been widely reported to lead to compounds of significantly greater potencies in 
the 4,5-dihydro-6-phenylpyridazin-3(2H)-ones. On the other hand, the tricyclic 4amethylpyridazinones showed similar levels of inotropic, vasodilator and PDE III inhibitory potencies to their normethyl analogues. In this series of compounds, the tricyclic 4amethylpyridazinones (11) with $\mathrm{R}=$ cyano, $\mathrm{CONH} 2, \mathrm{NH} 2, \mathrm{NHAc}$, or OMe, and $\mathrm{n}=1,2, \ldots$, showed good inotropic, vasodilator and PDE III inhibitory potencies.<smiles>[R]c1ccc2c(c1)CC1(C)CC(=O)NN=C21</smiles>

$\mathrm{R}=$ cyano, $\mathrm{CONH}_{2}, \mathrm{NH}_{2}, \mathrm{NHAc}, \mathrm{OMe}, \mathrm{n}=1,2, \ldots$.

11

Jiang and Sun [39] synthesized 6-(4-substituted phenyl)-4,5-dihydro-3(2H)-pyridazinones and demonstrated that compound (12) was a good inhibitor of platelet aggregation in rats. Preliminary pharmacological tests of the other compounds revealed that they inhibited ADP. induced platelet aggregation.

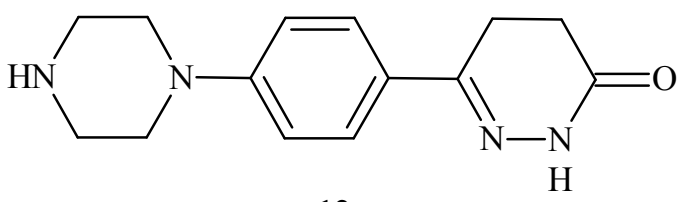

12

Lee et al [40] have reported potential antihypertensive properties of 8-methyl derivatives of 6-(1,4,5,6-tetrahydro-6oxopyridazin-3-yl)-1,2,3,4-tetrahydro-1-oxo- $\beta$ carboline. In vitro studies revealed that compound (13) exhibited particularly potent and long lasting hypotensive activity. Molecular modeling also revealed that this compound (13) met all the stipulations of 5-point model required for inhibition of cAMP phosphodiesterase activity.

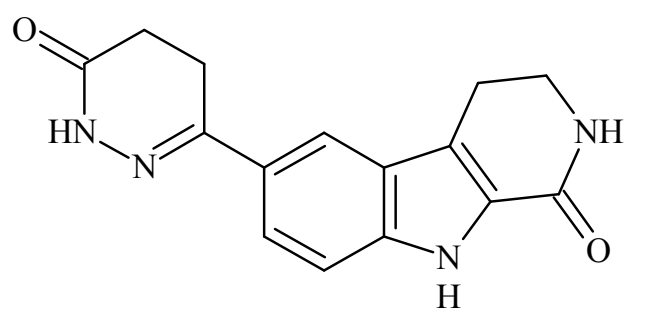

13

A series of 6-[4-(amino)phenyl]-4,5dihydropyridazin-3(2H)-ones (14) derivatives with $\mathrm{R}=\mathrm{H}, \mathrm{Me} ; \mathrm{R}_{1}=\mathrm{R}_{2}=$ alkyl; $\mathrm{R}_{1} \mathrm{R}_{2}=$ piperazinyl, piperidinyl, and related compounds have been evaluated as inhibitors of cardiac cAMP phosphodiesterase (cAMP PDE) by Abou-Zeid et al [41]. However, none of the tested compounds exhibited considerable inhibitory activity on cAMP PDE.

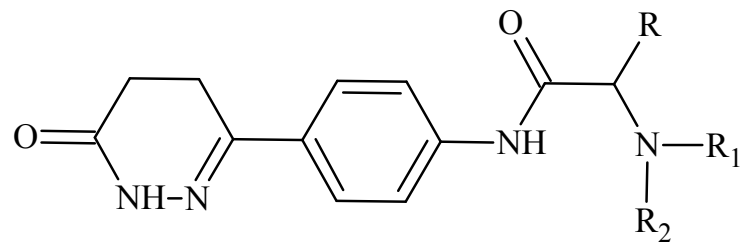

14

Abou-Zeid et al [42] have also reported synthesis of positive inotropic 6-substituted 4,5dihydropyridazin-3(2H)-ones, for example compound (15) with $\mathrm{Z}=\mathrm{O}, \mathrm{S}$; $\mathrm{R}=\mathrm{H}, \mathrm{OH}$, Me; $\mathrm{R}_{1}=\mathrm{H}$, Me; $\mathrm{R}_{2}=\mathrm{R}_{3}=\mathrm{H}$, and alkyl; and a ring between $R_{2}$ and $R_{3}$. An example of these compounds is compound (16).

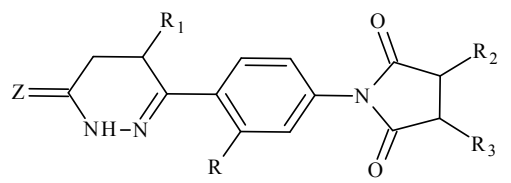

$\mathrm{Z}=\mathrm{O}, \mathrm{S} ; \mathrm{R}=\mathrm{H}, \mathrm{OH}, \mathrm{Me} ; \mathrm{R} \quad{ }_{1}=\mathrm{H}, \mathrm{Me} ; \mathrm{R} \quad{ }_{2}, \mathrm{R}_{3}=\mathrm{H}$, alkyl; $\mathrm{R} \quad{ }_{2} \mathrm{R}_{3}$ form a ring<smiles>O=C1CCC(c2ccc(N3C(=O)CCC3=O)cc2)=NN1</smiles>

The synthesis and platelet aggregation-inhibitory activities of 6-(4-substituted acylamidophenyl)4,5-dihydro-3(2H)-pyridazinones and 6-(4substituted acylaminophenyl)-4,5-dihydro-3(2H)pyridazonones have been described by Liu et al $[43,44]$. Preliminary pharmacological tests revealed that all the synthesized compounds inhibited appreciable ADP-induced platelet aggregation activities in rabbits. Liu et al [45] have further reported synthesis of 6-(4substituted acylaminophenyl)-4,5-dihydro-3(2H)pyridazinones and their inhibitory actions on platelet aggregation. These compounds were synthesized based on structure-activity relationships of anti-platelet aggregation of dihydropyridazinones. The synthesized compounds showed different levels of inhibitory activities on ADP induced-platelet aggregation. Synthesis of 6-(4-(substituted amino) phenyl)4,5-dihydropyridazin-3(2H)-ones as potential positive inotropic agents has been described by Abou-Zeid et al [46]. Some of the synthesized compounds exhibited good positive inotropic effects. 
The synthesis and anti-platelet aggregation activities of 6-(4-substituted acylaminophenyl)4,5-dihydro-3(2H)-pyridazinones have been reported by Liu et al [47]. These compounds appreciably inhibited ADP-induced platelet aggregation, with some having more potencies than the standard compound, Cl-930. Zhao et al [48] have reported synthesis of analogues of pyridazinones and their inhibition of platelet aggregation, with evidence of their ADP-induced platelet-inhibitory activities.

Zhao and Liu [49] have reported synthesis of 6substituted acylpiperazinyl phenyl dihydro pyridazinones and their inhibition of platelet aggregation. Preliminary in vitro tests showed that all the compounds were effective against platelet aggregation induced by ADP.

Synthesis and vasodilator activities of some [(4arylidene-2-phenyl-5-oxoimidazolin-1-yl) phenyl]4,5-dihydro-3(2H)-pyridazinones and 4-[(4arylidene-2-phenyl-5-oxoimidazolin-1-yl)phenyl]$1(2 H)$-phthalazinones have been reported by Demirayak et al [50]. The most significant decrease in blood pressure in vivo occurred with compound (17).<smiles>Cc1ccc(/C=C2\N=C(c3ccccc3)N(c3ccc(C4=NNC(=O)CC4)cc3)C2=O)cc1</smiles>

Demirayak et al [51] have also reported some pyrrole-substituted aryl pyridazinones, for example compound (18), and demonstrated that some of them had antihypertensive activities.<smiles>CCOC(=O)c1cc(-c2ccc(OC)cc2)n(-c2ccc(C3=NN(C)C(=O)CC3)cc2)c1C</smiles>

18

6-(4-substituted phenyl)-4,5-dihydro-3(2H)pyridazinones have been synthesized prepared as anti-thrombotic agents by Ren et al [52]. Preliminary in vitro tests revealed that all the synthesized compounds were active against platelet aggregation induced by ADP.

Synthesis and cardiovascular activities of 6-(4- aminophenyl)-2,3,4,5-tetrahydropyridazine-3-one derivatives have been studied by Dong et al [53]. Although these compounds possessed strong inotropic activities, they had little effect on the right atria of the rat in vitro. Wang et al. [54] synthesized series of 6-phenyl-4,5-dihydro$3(2 \mathrm{H})$-pyridazinones and studied their cardiotonic activities on isolated perfused toad heart, relative to levosimendan. From the series, compound (19) exhibited very potent cardiotonic activity.<smiles>CC1CC(=O)NN=C1c1ccc(NC(=O)c2cc(Cl)ccc2[N+](=O)[O-])cc1</smiles>

Three series of pyridazinones were designed as vasorelaxant agents using three dimensional pharmacophore developed with catalyst software by Khaled et al [55]. Several compounds with higher fit scores to the developed pharmacophore were synthesized, for example, 6-(3-ethoxycarbonyl-4-oxo-1,4-dihydroquinolin-6yl)-5-substituted-4,5-dihydro-3(2H)-pyridazinones (20) and 6-[4-(2,6-disubstituted quinolin-4ylamino)-2-substituted phenyl]-5-substituted-4,5dihydropyridazin-3(2H)-ones (21). The vasodilator activities of the newly synthesized compounds were examined on isolated main pulmonary rabbit arteries. Some of the tested compounds showed moderate vasorelaxant activities relative to the standard drug, Milrinone.<smiles>[R7]C1CC(=O)NN=C1c1ccc2[nH]cc(C(=O)OCC)c(=O)c2c1</smiles>

The anti-platelet aggregation activities of 6-(4substituted acetamido phenyl)-4,5-dihydro-3(2H)pyridazinones derived from different piperazine groups have been studied by Xu et al [56]. All the synthesized compounds had potent anti-platelet aggregation activities. It was also found that antiaggregation activity was influenced by the carbon chain length of the 4-substituted piperazine 
<smiles>[R]c1ccc2nc([R3])cc(Nc3ccc(C4=NNC(=O)CC4[R])c([R2])c3)c2c1</smiles>

group. Sun et al [57] synthesized and demonstrated anti-platelet aggregative activities of 6-(4-substituted acetamidophenyl)-4,5dihydro-3(2H)-pyridazinones bearing different heterocyclic groups. However stereospecific blockage and hydrophilicity of different heterocylic groups had impacts on the antiplatelet aggregative activities of these compounds.

Wang et al [21] has designed, synthesized and studied the structure-activity relationships of 6phenyl-4,5-dihydro-3(2H)-pyridazinone derivatives with respect to their cardiotonic properties. Among these compounds, 2,3-dichloro-N-(4-(4methyl-6-oxo-1,4,5,6-tetrahydropyridazin-3yl)phenyl) benzamide (22), 4-amino-3-methyl-N- (4-(4-methyl-6-oxo-1,4,5,6-tetrahydropyridazin-3yl)phenyl) benzamide (23), 3-methyl-4-nitro-N-(4(6-oxo-1,4,5,6-tetrahydropyridazin-3-yl)phenyl) benzamide (24) and 4-amino-3-methyl-N-(4-(6oxo-1,4,5,6-tetrahydropyridazin-3-yl) phenyl) benzamide (25) exhibited cardiotonic activities which were comparable to that of levosimendan.

Cai et al [58] reported anti-platelet aggregation activities of $\mathrm{N}$-[4-(1, 4, 5, 6-tetrahydro-6-oxo-3pyridazinyl) phenyl] acetamides. The in vitro activities of several of the derivatives were higher than that of $\mathrm{MCl}-154$ [4,5-dihydro-6-[4-(4pyridinylamino) phenyl]-3(2H)-pyridazinone hydrochloride]. It was also found that stereospecific blocking and hydrophilicity of different secondary amino groups in the target compounds affected their anti-platelet aggregation activities.

Chai et al [59] have reported synthesis and potent anti-platelet aggregation activities of 6-[4(substituted aminoacetamidophenyl)]-4,5dihydro-3(2H)-pyridazinones. It was also observed that the anti-platelet aggregation activities of the compounds were enhanced by introduction of different substituted amino groups enhanced. Thota et al [60] synthesized and reported significant anti-platelet aggregation<smiles>CC1CC(=O)NN=C1c1ccc(NC(=O)c2cccc(Cl)c2Cl)cc1</smiles><smiles>Cc1cc(C(=O)Nc2ccc(C3=NNC(=O)CC3C)cc2)ccc1N</smiles><smiles>Cc1cc(C(=O)Nc2ccc(C3=NNC(=O)CC3)cc2)ccc1[N+](=O)[O-]</smiles><smiles>Cc1cc(C(=O)Nc2ccc(C3=NNC(=O)CC3)cc2)ccc1N</smiles> 
activities of a series of 6-(4-(substituted amino) phenyl)-4,5-dihydro-3(2H)-pyridazinones. The compounds (26) and (27) displayed two times more platelet aggregation-inhibitory effects than the standard drug aspirin.<smiles>O=C1CCC(c2ccc(NCc3ccccc3O)cc2)=NN1</smiles><smiles>O=C1CCC(c2ccc(NCc3c[nH]c4ccccc34)cc2)=NN1</smiles>

Amin et al [61] successfully synthesized new 4,5$3(2 H)$-pyridazinone derivatives with the general formula (28), where $\mathrm{R}=$ alkyl, alkylamine, alkanoylamine or alkoxy group; $\mathrm{R}_{1}=$ alkyl, acetyl, COOEt, $\mathrm{CN} ;$ and $\mathrm{RR}_{1}=$ five membered heterocycle. The cardiotonic, hypotensive, and platelet-aggregation inhibition activities were also investigated. Results from in vitro studies of their positive inotropic effects on isolated rabbit heart revealed that twelve of the compounds exhibited higher effective responses than digoxin, while nine compounds were comparable to digoxin in their responses. However eight of the compounds were less active than digoxin.<smiles>[R]C(=O)/C([R])=N/Nc1ccc(C2=NNC(=O)CC2)cc1</smiles>

\section{CONCLUSION}

Cardiovascular disease has become the leading cause of death worldwide and remains the foremost cause of preventable death globally. The need for more research in the field of cardiovascular disease in developing countries is underscored by the prevalence of cardiovascular disease in all age group of patients in these countries. 6-(4-Aminophenyl)-4,5-dihydro-3(2H)pyridazinone is an important chemical moiety that is useful for the development of cardio-active agents. The potential of its derivatives as cardioactive agents is evident from the literature as reviewed in this article. It is our belief that the exploitation of 6-(4-aminophenyl)-4,5-dihydro$3(2 \mathrm{H})$-pyridazinone derivatives can produce more potent cardio-active agents for clinical use in the treatment of cardiovascular disease.

\section{DECLARATIONS}

\section{Acknowledgement}

The authors express their deepest appreciation to the Library Deanship, Northern Border University, for providing access to its databases used to carry out literature search for the preparation of this article.

\section{Conflict of Interest}

No conflict of interest associated with this work.

\section{Contribution of Authors}

The authors declare that this work was done by the authors named in this article and all liabilities pertaining to claims relating to the content of this article will be borne by them.

\section{REFERENCES}

1. Gaetano S. Epidemiology of cardiovascular disease in the 21st century: Updated numbers and updated facts. $J$ Cardiovasc Dis 2013; 1(1): 1-2.

2. Al-Sieni Al, Baghdadi MA, Al-Abbasi FA. Country wide statistical assessment of smoking induced atherosclerotic and metabolic risk factors in Saudi population. Asian J Pharm Health Sci 2014; 4(1): 916920.

3. Al-Mendalawi MD. Pediatric heart diseases in Madina, Saudi Arabia. Saudi Med J 2010; 31(8): 943-944.

4. Temilolu OA, Miller M. Cardiovascular disease: A global problem extending into the developing world. World $J$ Cardiol 2009; 1(1): 3-10. 
5. Reddy KS. Cardiovascular diseases in the developing countries: Dimensions, determinants, dynamics and directions for public health action. Public Health Nutr 2002; 5(1A): 231-237.

6. Steffen RP, Weishaar RE, Evans DB, Kaplan HR. Imazodan (Cl-914). Cardiovasc Drug Rev 1986; 4(1): 81-105.

7. Asif M, Anita S. Synthesis of new derivative of 2-[2-(1Hindol-1-yl)ethyl]-6-phenyl-4,5-dihydropyridazin-3(2H)one. Ovidius Univ Ann Chem 2011; 22(2): 98-101.

8. Xin-Sheng C, Hua-Wu Z, Yuang-Ying J, Wei-Qin W, Kun L. Effect of Cl-930, a novel phosphodiestrase III inhibitor, on platelet aggregation and arachidonic acid metabolism. Acta Pharmacol Sin 1990; 11(4): 338-343.

9. Dobariya TD, Multani PJ. Development and validation of methods for estimation of pimobendan in pharmaceutical dosage form. Int $J$ ChemTech Res 2013; 5(5): 2154-2164.

10. Kauffman RF, Utterback BG, Robertson DW. Specific binding of [3H]LY186126, an analogue of indolidan (LY195115), to cardiac membranes enriched in sarcoplasmic reticulum vesicles. Circ Res 1989; 64(5): 1037-1040.

11. Nieminen MS, Fruhwald S, Heunks LMA, Suominen PK, Gordon AC, Kivikko M, Pollesello P. Levosimendan: Current data, clinical use and future development. Heart Lung Vessel 2013; 5(4): 227-245.

12. Kumar D, Carron R, De La Calle D, Jindal DP, Bansal R. Synthesis and evaluation of 2-substituted-6-phenyl-4,5dihydropyridazin-3(2H)-ones as potent inodilators. Acta Pharm 2008; 58: 393-405.

13. Hiroshi M, Tohru N, Kazuhiro G. Y-590 (A new pyridazinone derivative), a potent anti-thrombotic agentI. Effect on platelet function. Thromb Res 1983; 31(4): 599-609.

14. Jonas $R$, Klockow $M$, Lues I, Prucher H, Schliep HJ, Wurziger $H$. Synthesis and biological activities of meribendan and related heterocyclic benzimidazolopyridazinones. Eur J Med Chem 1993; 28(2): 129-140.

15. Mochizuki N, Uchida S, Miyata H. Cardiovascular effects of NSP-804 and NSP-805, novel cardiotonic agents with vasodilator properties. J Cardiovasc Pharmacol 1993; 21(6): 983-995.

16. Moore JBJ, Combs DW, Tobia AJ. Bemoradan - a novel inhibitor of the rolipram insensitive cyclic AMP phosphodiesterase from canine heart tissue. Biochem Pharmacol 1991; 42(3): 679-683.

17. Bansal R, Thota S. Pyridazin-3(2H)-ones: The versatile pharmacophore of medicinal significance. Med Chem Res 2013; 22: 2539-2552.

18. Warren SE, Kihara Y, Pesaturo J, Gwathmey JK, Phillips $P$, Morgan JP. Inotropic and lusitropic effects of $\mathrm{MCl}$ 154 (6-[4-(4-pyridyl)aminophenyl]-4,5-dihydro-3(2H)pyridazinone) on human myocardium. J Mol Cell Cardiol 1989; 21(10): 1037-1045

19. Johan AB, Richard FW, Robert SS, Charles K, William CF, Henry FC, Mark HP. Pharmacology of RG W-2938:
A cardiotonic agent with vasodilator activity. $J$ Cardiovasc Pharmacol 1990; 16(4): 537-545.

20. Kenneth JM, Roger JE, John SD, David CG, Catherine AS, Bella $P$, Aileen K, Angela $W$, James AL, William JC. The effect of SK\&F 95654, a novel phosphodiesterase inhibitor, on cardiovascular, respiratory and platelet function. Br J Pharmacol 1992; 107: 463-470.

21. Wang T, Dong Y, Wang L, Xiang B, Chen Z, Qu L. Design, synthesis and structure activity relationship studies of 6-phenyl-4,5-dihydro-3(2H)-pyridazinone derivatives as cardiotonic agents. Arzneim Forsch 2008; 58(11): 569-573.

22. Pooja BS. Various biological activities of pyridazinone ring derivatives. Asian J Chem 2011; 23(5): 1905-1910.

23. Singh TA, Verma $P$, Anish C. A review on biological profile of pyridazinone containing drugs. Asian $J$ Res Chem 2010; 3(2): 265-271.

24. Asif $M$, Singh $A$, Siddiqui $A A$. The effect of pyridazine compounds on the cardiovascular system. Med Chem Res 2012; 21: 3336-3346.

25. Khaidem S, Sarveswari S, Gupta R, Vijayakumar V. Synthesis and biological evaluation of some pyridazinone derivatives. Int J Res Pharm Chem 2012; 2(2): 258-266.

26. Gerhard B, August A. 6-Aminophenyl- and 6acylaminophenyl-4,5-dihydropyridazones-(3). French Patent Number 1,507,475 1967: 1-2.

27. Gerhard B, August A. 6-Aminophenyl- and 6acylaminophenyl-4,5-dihydropyridazones-(3). United States Patent Number 3,475,431 1969: 1.

28. Curran WV, Ross A. 6-Phenyl-4,5-dihydro-3(2H)pyridazinones. A series of hypotensive agents. J Med Chem 1974; 17(3): 273-281.

29. Thyes M, Lehmann HD, Gries J, Koenig H, Kretzschmar $R$, Kunze J, Lebkuecher R, Lenke D. 6-Aryl-4,5-dihydro$3(2 \mathrm{H})$-pyridazinones. A new class of compounds with platelet aggregation inhibiting and hypotensive activities. J Med Chem 1983; 26(6): 800-807.

30. Stein B, Fuster $V$, Israel $D H$, Cohen $M$, Badimon $L$, Badimon JJ, Chesebro JH. Platelet inhibitor agents in cardiovascular disease: An update. J Am Coll Cardiol 1989; 14(4): 813-836.

31. Gupta SP, Shewade DG, Garg C, Handa A, Prabhakar YS. A quantitative analysis of dependence of platelet aggregation inhibition and hypotensive activities of dihydropyridazinone derivatives on molecular size. Indian J Biochem Biophys 1985; 22(2): 122-125.

32. Sircar I, Duell BL, Bobowski G, Bristol JA, Evans DB. Cardiotonic agents. 2. Synthesis and structure activity relationships of 4,5-dihydro-6-[4-(1H-imidazol-1yl)phenyl]-3(2H)-pyridazinones: $A$ new class of positive inotropic agents. J Med Chem 1985; 28(10): 1405-1413.

33. Okushima $H$, Narimatsu $A$, Kobayashi $M$, Furuya $R$, Tsuda K, Kitada Y. A novel class of cardiotonics. Synthesis and pharmacological properties of [4(substituted-amino)phenyl]pyridazinones and related derivatives. J Med Chem 1987; 30(7): 1157-1161. 
34. Sircar I, Weishaar RE, Kobylarz D, Moos WH, Bristol JA. Cardiotonic agents. 7. Inhibition of separated forms of cyclic nucleotide phosphodiesterase from guinea pig cardiac muscle by 4,5-dihydro-6-[4-(1H-imidazol-1yl)phenyl]-3(2H)-pyridazinones and related compounds. Structure activity relationships and correlation with in vivo positive inotropic activity. J Med Chem 1987; 30(11): 1955-1962.

35. Slater RA, Howson W, Swayne GTG, Taylor EM, Reavill $D R$. Design and synthesis of a series of combined vasodilator- $\beta$-adrenoceptor antagonists based on 6arylpyridazinones. J Med Chem 1988; 31(2): 345-351.

36. Stefano C, Giovannella S, Codagnone A. Synthesis and antihypertensive properties of benzodioxanepyridazinones and benzodioxane-dihydropyridazinones synthese und antihypertensive eigenschaften von benzodioxan-pyridazinonen und benzodioxandihydropyridazinonen. Arch Pharm 1989; 322(11): 833835.

37. Alfred M, Friebe WG, Mueller-Beckmann B, Kampe W, Kling L, Wolfgang VS. Nonsteroidal cardiotonics. 3. New 4,5-dihydro-6-(1H-indol-5-yl)-pyridazin-3(2H)-ones and related compounds with positive inotropic activities. $J$ Med Chem 1990; 33(10): 2870-2875.

38. Bakewell SJ, Coates WJ, Comer MB, Reeves ML, Warrington $\mathrm{BH}$. Inotropic, vasodilator and low $\mathrm{Km}$, cAMP-selective, cGMP-inhibited phosphodiesterase (PDE III) inhibitory activities of 4a-methyl-4,4a-dihydro$5 \mathrm{H}$-indeno[1,2-c]pyridazin-3(2H)-ones and 4a-methyl4,4a,5,6-tetrahydrobenzo[h]cinnolin-3(2H)-ones. Eur $J$ Med Chem 1990; 25(9): 765-774.

39. Jiang $Q$, Sun $C S$. Synthesis and platelet aggregation inhibitory activity of 6-(4-substitutedphenyl)-4,5-dihydro3(2H)-pyridazinones. Yaoxue Xuebao 1990; 25(8): 598603.

40. Lee AR, Huang WH, Sun IC, Lee HF. Synthesis of 6(1,4,5,6-tetrahydro-6-oxopyridazin-3-yl)-1,2,3,4tetrahydro-1-oxo- $\beta$-carboline and its 8-methyl derivative as potential antihypertensive agents. Zhonghua Yaoxue Zazhi 1993; 45(6): 551-562.

41. Abou-Zeid KAM, Youssef KM, Shaaban MA, El-Telbany FA, Al-Zanfaly SH. 6-[4-(Substitutedamino)phenyl]-4,5dihydropyridazin-3(2H)-ones as cardiotonic agents. Bull Fac Pharm Cairo Univ 1995; 33: 9-12.

42. Abou-Zeid KAM, Youssef KM, Shaaban MA, El-Telbany FA, Al-Zanfaly SH. Synthesis and phosphodiesterase inhibiting activity of some 6-substituted-4,5dihydropyridazin-3(2H)-ones. Bull Fac Pharm Cairo Univ 1995; 33: 25-28.

43. Liu C, Zhang G, Zhu W, Miao H, Jin Y. Synthesis and platelet aggregation inhibitory activity of 6-(4substitutedacylamidophenyl)-4,5-dihydro-3-(2H)pyridazinones. Zhongguo Yiyao Gongye Zazhi 1998; 29(8): 349-351.

44. Liu C, Zhang Z, Wu Q, Wu Y, Zhang D. Synthesis and platelet aggregation inhibitory activity of 6-(4substitutedacylaminophenyl)-4,5-dihydro-3(2H)- pyridazonones. Zhongguo Yaowu Huaxue Zazhi 1998; 8(3): 163-168.

45. Liu C, Zhang Z, Lu B, Wu Q, Zhang D. Synthesis of dihydropyridazinones and their inhibitory action to platelet aggregation. Zhongguo Yaowu Huaxue Zazhi 1998; 8(4): 254-259.

46. Abou-Zeid KAM, Youssef KM, Shaaban MA, El-Telbany FA, Al-Zanfaly SH. Synthesis of 6-(4-(substituted amino)phenyl)-4,5-dihydropyridazin-3(2H)-ones as potential positive inotropic agents. Egypt J Pharm Sci 1998; 38: 319-331.

47. Liu C, Xue K, Yao J, Jiang Y, Lu B, Wu Y. Synthesis of 6(4'-substitutedacylaminophenyl)-4,5-dihydro-3-(2H)pyridazinones and inhibitory activity on platelet aggregation. Yaoxue Xuebao 1999; 34(1): 23-28.

48. Zhao D, Liu C, Wu Q, Zhang D. Synthesis of analogues of pyridazinones and their inhibition of platelet aggregation. Dier Junyi Daxue Xuebao 2002; 23(2): 215-217.

49. Zhao D, Liu C. Synthesis of 6-substituted acylpiperazinyl phenyl dihydro pyridazinones and their inhibition of platelet aggregation. Dier Junyi Daxue Xuebao 2003; 24(5): 510-513.

50. Demirayak S, Karaburun AC, Kayagil I, Erol K, Sirmagul $B$. Some pyridazinone and phthalazinone derivatives and their vasodilator activities. Arch Pharm Res 2004; 27(1): 13-18.

51. Demirayak S, Karaburun AC, Beis R. Some pyrrole substituted aryl pyridazinone and phthalazinone derivatives and their antihypertensive activities. Eur $J$ Med Chem 2004; 39(12): 1089-1095.

52. Ren $H, \quad W u \quad Q$, Song B. Synthesis of 6-(4substitutedphenyl)-4,5-dihydro-3(2H)-pyridazinone analogs and study on their platelet aggregation inhibitory activity. Huaxi Yaoxue Zazhi 2004; 19(1): 1921.

53. Dong $Y$, Wang $L$, Jiang Z, Jia $X$. Synthesis and bioactivity of 6-(4-aminophenyl)-2,3,4,5-tetrahydropyridazine-3-one derivatives. Zhongguo Yaowu Huaxue Zazhi 2005; 15(2): 80-84.

54. Wang T, Dong Y, Wang L, Chen Z. Synthesis and bioactivity of 6-phenyl-4,5-dihydro-3(2H)-pyridazinone derivatives. Arzneim Forsch 2007; 57(10): 641-646.

55. Khaled A, Maha AK, Omnya K, Yosria M. Pyridazinone derivatives: Design, synthesis, and in vitro vasorelaxant activity. Bioorg Med Chem 2008; 16(1): 382-389.

56. $X u Y$, Huang $X, X u J$, Cai L, Song $Y$, Zhao $Q, W u Q$. Synthesis and antiplatelet aggregation activity of 4,5dihydro-3(2H)-pyridazinones. Yaoxue Shijian Zazhi 2008; 26(3): 175-177.

57. Sun L, Huang $X$, Fan S, Yu S, Wu Q. Synthesis and the antiplatelet aggregative activity of 6-(4substitutedacetamidophenyl)-4,5-dihydro-3(2H)pyridazinones. Yaoxue Shijian Zazhi 2008; 26(4): 278281.

58. Cai L, Xu J, Hu H, Song Y, Sun L, Yu S, Wu Q. Synthesis and antiplatelet aggregation activities of 6-(4substitutedacetamidophenyl)-4,5-dihydro-3(2H)- 
pyridazinones. Zhongguo Yaowu Huaxue Zazhi 2007; 17(4): 209-212.

59. Chai X, Zhang C, Hu H, Zhao Q, Dan Z, Zou Y, Yu S, Wu $Q$. Synthesis and antiplatelet aggregation activity of 6[4-(substitutedaminoacetamidophenyl)]-4,5-dihydro3(2H)-pyridazinones. Yaoxue Shijian Zazhi 2008; 26(6): 444-446.
60. Thota S, Bansal R. Synthesis of new pyridazinone derivatives as platelet Aaggregation inhibitors. Med Chem Res 2010; 19(8): 808-816.

61. Amin EN, Abdel-Alim AM, Abdel-Moty SG, El-Shorbagi AA, Abdel-Rahman MS. Synthesis of new 4,5-3(2H)pyridazinone derivatives and their cardiotonic, hypotensive, and platelet aggregation inhibition activities. Arch Pharm Res 2010; 33(1): 25-46. 